удК 616.311-022.7-06:616.12-002.]-084

DOI 10.11603/2311-9624.2018.4.9747

()О. О. Мигаль, Р. З. Огоновський

Львівський національний медичний університет імені Данила Галицького

(ostap.myhal@gmail.com)

\title{
Сучасні аспекти профілактики бактеріємії у пацієнтів із хронічною ревматичною хворобою серця в стоматологічній практиці
}

Резюме. Хронічна ревматична хвороба серця (ХРХC) виникає унаслідок перенесеної гострої ревматичної лихоманки із формуванням вади серця в результаті запалення, спричиненого $\beta$-гемолітичним стрептококом групи А, через уповільнення імунної відповіді на стрептококову інфекцію та подальшого розвитку крайового фіброзу та склерозу сполучної тканини клапанів серця. Близько 60 \% пацієнтів із гострою ревматичною лихоманкою із часом мають ХРХС, із найвищою частотою клапанних уражень серця протягом 1-3 років від першої атаки гострої ревматичної лихоманки.

Мета дослідження - представити лікарям-стоматологам сучасні аспекти профілактики транзиторної бактеріємії у пацієнтів із хронічною ревматичною хворобою серця (XPXC) та опрацювати рекомендації щодо терапевтичного супроводу даної диспансерної групи.

Матеріали і методи. Проведено огляд та аналіз науково-медичної літератури за 2008-2018 рр., звітних матеріалів методично-наукових організацій, діючих нормативно-правових документів. Виокремлено основні напрямки профілактики ускладнень перебігу ХРХС, пов’язані з медичними втручаннями, зокрема надання стоматологічної допомоги, супровід осіб із стоматологічними захворюваннями.

Результати досліджень та їх обговорення. Розглянуто питання необхідності оновлення стоматологічних підходів у терапевтичному супроводі пацієнтів із хронічною ревматичною хворобою серця. Представлено сучасні схеми антимікробної профілактики та нормативних документів при стоматологічних втручаннях з урахуванням ризиків транзиторної бактеріємії.

Висновки. У зв'язку зі зростанням частки загострення та ускладнень хронічної ревматичної хвороби серця, асоційованих з медичним втручанням, індивідуалізація стоматологічної профілактики транзиторної бактеріємії у даних пацієнтів набуває визначального значення. Тому для досягнення високого рівня стоматологічної санованості необхідне удосконалення заходів специфічної та неспецифічної профілактики транзиторної бактеріємії, що надзвичайно важливо для попередження прогресування ускладнень хронічної ревматичної хвороби серця.

Ключові слова: хронічна ревматична хвороба серця; транзиторна бактеріємія; стоматологічна патологія; специфічна та неспецифічна профілактика.

\section{(с). О. Мыгаль, Р. 3. Огоновский}

Львовский национальный медицинский университет имени Данила Галицкого

\section{Современные аспекты профилактики бактериемии у пациентов с хронической ревматической болезнью сердца в стоматологической практике}

Резюме. Хроническая ревматическая болезнь сердца (ХРБС) возникает вследствие перенесенной острой ревматической лихорадки с формированием порока сердца в результате воспаления, вызванного $\beta$-гемолитическим стрептококком группы А, из-за замедления иммунного ответа на стрептококковую инфекцию и дальнейшего развития краевого фиброза и склероза соединительной ткани клапанов сердца. Около 60 \% пациентов с острой ревматической лихорадкой со временем имеют ХРБС, с высокой частотой клапанных поражений сердца в течение 1-3 лет от первой атаки острой ревматической лихорадки.

Цель исследования - представить врачам-стоматологам современные аспекты профилактики транзиторной бактериемии у пациентом с хронической ревматической болезнью сердца (ХРБС), а также рекомендации сопровождения данной диспансерной группы на приеме врача-стоматолога.

Материалы и методы. Проведен обзор и анализ научно-медицинской литературы по 2008-2018 гг., отчетных материалов методично-научных организаций, действующих нормативно-правовых документов. Выделены основные направления профилактики осложнений течения ХРБС, связанные с ме- 
дицинскими вмешательствами, в частности оказания стоматологической помощи, сопровождение лиц с стоматологическими заболеваниями.

Результаты исследований и их обсуждение. Рассмотрены вопросы необходимости обновления стоматологических подходов в терапевтическом сопровождении пациентов с хронической ревматической болезнью сердца. Представлены современные схемы антимикробной профилактики и нормативных документов при стоматологических вмешательствах с учетом рисков транзиторной бактериемии.

Выводы. В связи с ростом доли осложнений хронической ревматической болезни сердца, ассоциированных с медицинским вмешательством, индивидуализация стоматологической профилактики транзиторной бактериемии у данных пациентов приобретает определяющее значение. Поэтому для достижения высокого уровня стоматологической санированности необходимо совершенствование мер специфической и неспецифической профилактики транзиторной бактериемии, что чрезвычайно важно для предупреждения прогрессирования осложнений хронической ревматической болезни сердца.

Ключевые слова: хроническая ревматическая болезнь сердца; транзиторная бактериемия; стоматологическая патология; специфическая и неспецифическая профилактика.

\section{(C). O. Myhal, R. Z. Ohonovsky}

Danylo Halytskyi Lviv National Medical University

\section{Modern aspects of prevention of bacteremia in patients with chronic rheumatoid heart disease in dental practice}

Summary. Chronic rheumatic heart disease (CRHD) occurs as a result of a severe acute rheumatic fever with heart failure as a result of inflammation caused by $\beta$-hemolytic group A streptococcus due to the slowing down of the immune response to streptococcal infection and the further development of boundary fibrosis and sclerosis of the connective tissue of the valvular heart. Approximately $60 \%$ of patients with acute rheumatic fever have, with time, CRHD, with the highest frequency of valvular heart disease within 1-3 years of the first attack of acute rheumatic fever [1].

The aim of the study - to present to dentists modern aspects of prevention of transient bacteremia in patients with chronic rheumatic heart disease (CRHD), as well as recommendations to accompany this dispensary group at the reception of a dentist.

Materials and Methods. A review and analysis of the scientific and medical literature for 2008-2018, reporting materials of methodological and scientific organizations, current regulatory documents. The main directions for the prevention of complications of the course of chronic respiratory distress syndrome associated with medical interventions, in particular the provision of dental care, accompaniment to persons with dental diseases are highlighted.

Results and Discussion. The issues of the need to update dental approaches in the therapeutic accompaniment of patients with chronic rheumatic heart disease were considered. Modern schemes of antimicrobial prophylaxis and regulatory documents for dental interventions, taking into account the risks of transient bacteremia are presented.

Conclusions. Due to the growing share of complications of chronic rheumatic heart disease associated with medical intervention, the individualization of dental prophylaxis of transient bacteremia in these patients becomes crucial. Therefore, in order to achieve a high level of dental sanitation, it is necessary to improve the measures of specific and nonspecific prevention of transient bacteremia, which is extremely important for preventing the progression of complications of chronic rheumatic heart disease.

Key words: chronic rheumatic heart disease; transient bacteremia; dental pathology; specific and non-specific prophylaxis.

Вступ. Хронічна ревматична хвороба серця (ХРХC) виникає унаслідок перенесеної гострої ревматичної лихоманки із формуванням вади серця в результаті запалення, спричиненого $\beta$-гемолітичним стрептококом групи А, через уповільнення імунної відповіді на стрептококову інфекцію та подальшого розвитку крайового фіброзу та склерозу сполучної тканини клапанів серця. Близько 60 \% пацієнтів із гострою ревматичною лихоманкою із часом мають ХРХC, із найвищою частотою клапанних уражень серця протягом 1-3 років 
від першої атаки гострої ревматичної лихоманки [1].

За визначенням В003, незважаючи на глобальне зниження показників захворюваності та смертності від ревматизму, що спостерігають упродовж 50-60 років, ускладнення ХРХС залишається значною медико-соціальною проблемою як у розвинутих країнах, так і в країнах, що розвиваються. Результати епідеміологічних досліджень останніх років, проведені в США та країнах Західної Європи, демонструють періодичне зростання захворюваності, спричиненої $\beta$-гемолітичним стрептококом групи А, яке супроводжуються зростанням захворюваності на гостру ревматичну лихоманку. Відсутність настороженості 3 боку лікарів призводить до збільшення частки асоційованого 3 медичним втручанням зростання захворюваності на ХРХС та збільшення швидкості його прогресування переважно в осіб працездатного віку, так як даний діагностований контингент осіб належить до особливо вразливої групи ризику щодо усіх інвазивних втручань [2].

ХРХС - це перш за все соціально залежне захворювання. Так, соціально-економічні фактори (бідність, недостатність харчування тощо) та відсутність настороженості медиків, зокрема лікарів-стоматологів, суттєво, хоча і не прямо, впливають на показники розвитку ХРХС [3]. Важливе значення тут відіграє адекватна вторинна профілактика при терапії поєднаних соматичних патологій, серед яких стоматологічні хвороби займають основну частку в попередженні розвитку транзиторної бактеріємії.

За епідеміологічними показниками більше 3 млн осіб страждає від симптомної серцевої недостатності унаслідок ХРХС, більша частина таких хворих потребує частих госпіталізацій та проведення оперативних втручань на серцевих клапанах протягом 5-10 років. Тому питання профілактики бактеріємії у хворих на ХРХС набувають значної актуальності для попередження зростання частоти випадків, асоційованих із медичним стоматологічним втручанням [4-6].

Метою дослідження стало представити лікарям-стоматологам сучасні аспекти профілактики транзиторної бактеріємії у пацієнтів із хронічною ревматичною хворобою серця (ХРХC) та опрацювати рекомендації щодо терапевтичного супроводу даної диспансерної групи.

Матеріали і методи. Проведено огляд та аналіз науково-медичної літератури за 2008-
2018 рр. Виокремлено основні напрямки щодо сучасного стану проблеми, діючі та рекомендовані схеми-протоколи етапів супроводу, профілактики та диспансеризації пацієнтів із XPXC на стоматологічному прийомі.

Результати досліджень та їх обговорення. Комплекс масових соціально-профілактичних заходів має займати визначальне місце в профілактиці запальних захворювань пародонта серед населення, у тому числі серед осіб із ХРХС. Тому важливим завданням стоматологічної служби є активне залучення цієї групи осіб до диспансеризації, організації системи профілактичних заходів щодо ЗП шляхом проведення профілактичних оглядів у ревматологічних відділеннях лікарень, використання можливостей формування контингенту індивідуального та колективного страхування, паспортизації стоматологічного здоров'я тощо [7].

Усвідомлення доцільності профілактики ХРХС надзвичайно важливе для лікарів-стоматологів, щелепно-лицевих хірургів, стоматологів-терапевтів та стоматологів-ортопедів [7-9]. Так, як у групу ризику виникнення транзиторної бактеріємії відносяться стоматологічні маніпуляції, що супроводжуються порушенням цілості слизової оболонки рота та періодонтальних тканин [10, 11]. Основну увагу необхідно звертати на кількісний та якісний склад мікрофлори порожнини рота та активність стрептококової мікрофлори, що реалізується діагностикою гігієнічного статусу ротової порожнини [12-15].

Для профілактики ХРХС доцільно використовувати антибіотикопрофілактику в пацієнтів із високим ризиком розвитку супутніх ускладнень [16] та застосовувати їх при проведенні стоматологічних процедур значного ризику (табл. 1).

Першорядну роль необхідно відводити дотриманню заходів гігієни, зокрема гігієни порожнини рота. Дані епідеміологічних досліджень свідчать, що унаслідок медичних процедур зростає частота транзиторної бактеріємії, зумовленої стафілококом, що приводить до важливості неспецифічних заходів асептики [17]. Останні не повинні поширюватися лише на хворих із високим ризиком, а застосовувати їх усім пацієнтам, оскільки частота ХРХС зростає.

Заходи специфічної антибіотикопрофілактики, рекомендовані для груп ризику щодо ускладнень із приводу транзиторної бактеріємії, при проведенні стоматологічних втручань представлені у таблиці 2. 
таблищя 1. Рекомендації з профілактики розвитку ризиків транзиторної бактеріємії у пацієнтів із хронічною ревматичною хворобою серця під час стоматологічних процедур

\begin{tabular}{|l|c|c|}
\hline \multicolumn{1}{|c|}{ Рекомендація } & Клас & Рівень \\
\hline $\begin{array}{l}\text { Антибіотикопрофілактику необхідно розглядати тільки при стоматологічних } \\
\text { процедурах, які потребують маніпуляцій на тканинах пародонта, періапікальних } \\
\text { тканинах та при порушенні цілості слизової оболонки порожнини рота }\end{array}$ & IIа & С \\
\hline $\begin{array}{l}\text { Антибіотикопрофілактику не рекомендують при проведенні місцево знеболю- } \\
\text { вальних ін’єкцій на неінфікованій тканині, лікуванні поверхневого карієсу, знятті } \\
\text { швів, рентгенографії зуба, встановленні й корекції ортодонтичних пристроїв, бре- } \\
\text { кетів, при втраті молочних зубів, травмах губ і слизової оболонки порожнини рота }\end{array}$ & & III \\
\hline
\end{tabular}

таблиия 2. Рекомендації щодо профілактичного контролю попередження бактеріємії при проведенні стоматологічних процедур у пацієнтів із хронічною ревматичною хворою серця

\begin{tabular}{|c|c|c|c|}
\hline \multirow{2}{*}{ Умова } & \multirow{2}{*}{ Антибіотик } & \multicolumn{2}{|c|}{ Одноразова доза за 30-60 хв до процедури } \\
\hline & & дорослі & діти \\
\hline $\begin{array}{l}\text { За відсутності алергії на } \\
\text { пеніцилін }\end{array}$ & $\begin{array}{c}\text { Амоксицилін або ампі- } \\
\text { цилін }{ }^{1}\end{array}$ & $\begin{array}{c}2 \text { г per os або внутрішньо- } \\
\text { венно }\end{array}$ & $\begin{array}{l}50 \mathrm{мг} / \text { кг per os або } \\
\text { внутрішньовенно }\end{array}$ \\
\hline $\begin{array}{l}\text { За наявності алергії на } \\
\text { пеніцилін або ампіцилін }\end{array}$ & Кліндаміцин & $\begin{array}{c}600 \text { мг per os або внутріш- } \\
\text { ньовенно }\end{array}$ & $\begin{array}{l}20 \text { мг/кг per os або } \\
\text { внутрішньовенно }\end{array}$ \\
\hline
\end{tabular}

Примітки: per os - перорально: 1) альтернатива: цефалексин 2 г внутрішньовенно або 50 мг/кг внутрішньовенно дітям; цефалозолін або цефтріаксон 1 г внутрішньовенно дорослим або 50 мг/кг внутрішньовенно дітям. Цефалоспорини не повинні застосовуватися в осіб з анафілаксією, ангіоневротичним набряком або уртикарним висипанням після застосування пеніциліну або ампіциліну в анамнезі через високу ймовірність перехресної чутливості;

2) дози препарату в педіатрії не повинні перевищувати такі у дорослих.

Згідно з рекомендаціями Британської асоціації Антимікробної Хіміотерапії (BSAC), антибіотикопрофілактика бактеріємії в осіб із бактерійним ендокардитом, до яких належать пацієнти з ХРХС, повинна здійснюватися таким способом, який представлено в табли- ці 3 [18]. Якщо курс лікування складається з декількох відвідувань, перевагу варто надавати амоксицикліну або кліндаміцину [19, 20]. Перед стоматологічними маніпуляціями полоскання 0,2 \% розчином хлоргекседином глюконатом (10 мл протягом 1 хв).

Таблищя 3. Рекомендації щодо антибіотикопрофілактики транзиторної бактеріємії на стоматологічному прийомі у пацієнтів з бактерійним ендокардитом групи ризику

\begin{tabular}{|c|c|c|c|c|}
\hline \multirow{2}{*}{ Умова } & \multicolumn{3}{|c|}{ Вік } & \multirow{2}{*}{$\begin{array}{c}\text { Час прийому препара- } \\
\text { ту перед стоматологіч- } \\
\text { ною процедурою }\end{array}$} \\
\hline & $>10$ років & $\geq 5$ до $<10$ років & $<5$ років & \\
\hline Загальні & $\begin{array}{c}\text { Амоксицилін } \\
3 \text { г per os }\end{array}$ & $\begin{array}{c}\text { Амоксицилін } \\
1,5 \text { г per os }\end{array}$ & $\begin{array}{l}\text { Амоксицилін } \\
750 \text { мг per os }\end{array}$ & За 1 год \\
\hline Алергія на пеніцилін & $\begin{array}{c}\text { Кліндаміцин } \\
600 \text { мг per os }\end{array}$ & $\begin{array}{l}\text { Кліндаміцин } \\
300 \text { мг per os }\end{array}$ & $\begin{array}{c}\text { Кліндаміцин } \\
150 \text { мг per os }\end{array}$ & За 1 год \\
\hline $\begin{array}{l}\text { Алергія на пеніцилін та } \\
\text { порушення здатності } \\
\text { ковтання капсул }\end{array}$ & $\begin{array}{c}\text { Азитроміцин } \\
500 \text { мг per os }\end{array}$ & $\begin{array}{c}\text { Азитроміцин } \\
300 \text { мг per os }\end{array}$ & $\begin{array}{c}\text { Азитроміцин } \\
200 \text { мг per os }\end{array}$ & За 1 год \\
\hline
\end{tabular}

Основні принципи профілактики транзиторної бактеріємії в осіб із ХРХС:

1. Зберігаються принципи антибіотикопрофілактики при проведенні маніпуляцій, асоційованих із розвитком супутніх ускладнень при ХРХС.

2. Стоматологічні процедури, що вимагають антибіотикопрофілактики, повинні бути об- межені у пацієнтів із тяжким перебігом ХРХС до досягнення компенсованого перебігу основного захворювання.

3. Для зниження ризику виникнення та обтяження перебігу ХРХС базовою є ретельна гігієна порожнини рота і регулярні огляди стоматолога. Антибіотикопрофілактику вважають як корегувальний i/або доповнювальний захід. 
4. Для зниження частоти ХРХС, асоційованого 3 медичними втручаннями, особливо при будь-яких стоматологічних інвазивних втручаннях, обов'язковим є ретельне дотримання правил асептики й антисептики.

5. Планові стоматологічні втручання здійснюють за 2 тижні до оперативних втручань, якщо пацієнту рекомендоване протезування клапана серця або імплантація інших чужорідних матеріалів у серце та судини, за винятком ургентних втручань.

До неспецифічних профілактичних заходів у пацієнтів із ХРХС необхідно віднести:

1. Ретельну гігієну порожнини рота та шкіри. Профілактичні огляди в стоматолога кілька разів на рік для осіб із ХРХС залежно від стоматологічного статусу.

2. Знезараження ран, особливо в порожнині рота.

3. Санація вогнищ хронічної інфекції: множинний карієс, хронічні пульпіти, періодонтити, генералізовані пародонтити тощо.

4. Застосування антибіотиків при будь-якій фокальній бактеріальній інфекції.

5. Застереження від самолікування антибіотиком, роз'яснювальну роботу.

6. Суворе дотримання правил асептики й антисептики при проведенні будь-яких стоматологічних процедур.

7. Уникати пірсингу язика та губ.

8. Обмежити за можливістю використовувати інвазивні процедури. Основний акцент ставити на попередженні стоматологічних ускладнень та методиках малоінвазивних втручань на тканинах пародонта.

Заходи щодо попередження виникнення ЗП та їх загострень у пацієнтів із ХРХС мають бути спрямовані на запобігання ушкодження зубоутримувальних структур та етіотропний контроль гігієнічного статусу. Останні повинні включати навчання індивідуальному догляду та гігієні порожнини рота, професійного догляду за ротовою порожниною та іншими стоматологічними ускладненнями, що розвиваються під впливом ГРЛ та ХРХС, а також рекомендовано моніторинг разом із лікаремревматологом.

Навчання індивідуальному догляду та гігієні порожнини рота:

1. Навчання пацієнта методу та техніці гігієнічного догляду за ротовою порожниною включає: мотивацію до регулярних заходів та індивідуальний підбір засобів гігієни.

2. Не використовувати рідини для полоскання рота, що містять спирт, лаурилсульфат натрію, натомість використання $\mathrm{pH}$ збалансованих ополіскувачів.

3. Використання ремінералізуючих засобів, що містять казеїн фосфопептид та аморфний фосфат кальцію (СРР-АСР).

4. Індивідуальне місцеве застосування лікувально-профілактичних засобів гігієни порожнини рота пародонтопротекторної спрямованості.

5. Оптимальна гігієна зубних протезів, регулярне їх чищення із застосуванням хлоргексидину біглюконату $0,2 \%$ (10 мл протягом 1 хв).

6. Усунення шкідливих звичок (відмова від тютюнокуріння, зниження вживання кави i чаю).

Професійний догляд за ротовою порожниною:

1. Регулярне проведення лікарем-стоматологом контролю за гігієнічним станом порожнини рота із застосуванням індикаторних речовин.

2. Регулярний стоматологічний огляд з метою раннього виявлення ЗП та попередження руйнування зубоепітеліального прикріплення.

3. Повноцінна санація порожнини рота, усунення травматичних факторів, ортодонтичне та ортопедичне лікування.

4. Професійна гігієна порожнини рота з видаленням зубних відкладень за максимальним забезпеченням відсутності інфікованої аерозольної хмари.

5. Застосування ремінералізуючих і фторвмісних засобів (лаків та гелів).

Висновки. У зв'язку зі зростанням частки загострень та ускладнень на хронічну ревматичну хворобу серця, асоційованої 3 медичним втручанням, стоматологічна профілактика транзиторної бактеріємії набуває визначального значення. Підтримання оптимального здоров'я гігієни порожнини рота та дотримання основних аспектів специфічної та неспецифічної профілактики дозволить знизити частоту виникнення транзиторної бактеріємії, контролювати іiі рівень, що надзвичайно важливо для попередження ускладнень прогресування хронічної ревматичної хвороби серця. 


\section{Список літератури}

1. Тіхончук Н. С. Застосування озонотерапії в комплексному лікуванні хворих з мітральними вадами серця ревматичної етіології : автореф. дис. на здобуття наук. ступеня канд. мед. наук / Н. С. Тіхончук. - Одеса, 2008. - 16 с.

2. Лисенко Г. І. Сучасні проблемні питання гострої ревматичної лихоманки / Г. І. Лисенко, Л. В. Хіміон // Український ревматологічний журнал. - 2013. - Т. 4 (54). - С. 6-12.

3. Волосовець Т. М. Сучасні стратегії міждисциплінарного запобігання інфекційному ендокардиту: стоматологічні аспекти / Т. М. Волосовець, О. В. Дорошенко // Новини стоматології. - 2014. - Т. 2 (79). C. 30-34.

4. Боярчук О. Р. Особливості субклінічного перебігу хронічної ревматичної хвороби серця / О. Р. Боярчук//Український ревматологічний журнал. -2012.T. 2 (48). - C. 28-32.

5. Хронічна ревматична хвороба серця і тактика її лікування / С. Ю. Кулявець, Е. П. Каменська, Л. О. Мартим'янова, М. І. Яблучанський // Медицина транспорту України. - 2013. - № 3. - С. 75-79.

6. Профілактика, діагностика та лікування інфекційного ендокардиту: рекомендації робочої групи 3 хвороб міокарда, перикарда, ендокарда та клапанів серця Асоціації кардіологів України / В. М. Коваленко, О. Г. Несукай, Г. В. Книшов [та ін.] // Український кардіологічний журнал. - 2015. - № 6. - С. 11-24.

7. Stewart R. Increasing evidence for an association between periodontitis and cardiovascular disease / R. Stewart, M. West // Circulation. - 2016. - No. 133. P. 549-551.

8. Oral manifestations of hypertension and rheumatic heart disease: A cross sectional study in elderly patients / M. Farzin, R. Derafshi, J. Ghapanchi [et al.] // Asian J. Med. Pharm. Res. - 2016. - Vol. 6 (2). - P. 09-13. 9. Teles R. Mechanisms involved in the association between peridontal diseases and cardiovascular disease / R. Teles, C.-Y. Wang // J. Oral Diseases. - 2011. Vol. 17 (5). - P. 450-461.

10. Cruz-Pamplona M. Dental considerations in patients with heart disease / M. Cruz-Pamplona, Y. JimenezSoriano, M. G. Sarrión-Pérez // J. Clin. Exp. Dent. - 2011. - Vol. 3 (2). - P. 97-105.

\section{References}

1. Tikhonchuk, N.S. (2008). Zastosuvannia ozonoterapii $\mathrm{v}$ kompleksnomu likuvanni khvorykh z mitralnymy vadamy sertsia revmatychnoi etiolohii [Application of ozonotherapy in complex treatment of patients with mitral defects of heart rheumatic etiology]. Candidate's Extended abstract. Odesa [in Ukrainian].

2. Lysenko, H.I., \& Khimion, L.V. (2013). Suchasni problemni pytannia hostroi revmatychnoi lykhomanky [Modern issues of acute rheumatic fever]. Ukrainskyi revmatolohichnyi zhurnal - Ukrainian Rheumatologist Journal, 4 (54), 6-12 [in Ukrainian].

3. Volosovets, T.M., \& Doroshenko, O.V. (2014). Suchasni stratehii mizhdystsyplinarnoho zapobihannia infektsiinomu endokardytu: stomatolohichni aspekty [Modern strategies for snterdisciplinary prevention of infectious endocarditis: dental aspects]. Novyny
11. Maharaj D. Oral health of patients with severe rheumatic heart disease / D. Maharaj, A. C. Vayej // Cardiovascular Journal of Africa. - 2012. - Vol. 23 (5). P. 336-339.

12. Dhotre S. V. Periodontitis, bacteremia and infective endocarditis: A review study / S. V. Dhotre, M. S. Davane, B. S. Nagoba // Arch. Pediatr. Infect. Dis. - 2017. - Vol. 5 (3). - P. e41067.

13. Nakano K. Streptococcus mutans and cardiovascular diseases / K. Nakano, R. Nomura, T. Ooshima // Japanese Dental Science Review. - 2008. - Vol. 44 (1). - P. 29-37.

14. Relationship between cardiovascular risk factors and periodontal disease: Current knowledge, cardiovascular risk factors / S. Granados-Principal, N. El-Azem, J. L. Quiles [et al.]; In A. Gasparyan ed. - InTech, 2012. Available from:

15. http://www.intechopen.com/books/cardiovascularrisk-factors/relationshipbetween-cardiovascular-riskfactors-and-periodontal-disease-current-knowledge

16. Dinakaran V. Microbial translocation in the pathogenesis of cardiovascular diseases: A microbiome perspective / V. Dinakaran // Journal of Cardiology \& Current Research. - 2017. - Vol. 8 (6). - P. 00305.

17. Вольф Г. Ф. Пародонтология : руководство / Г. Ф. Вольф, Э. М. Ратейцхак, К. Ратейцхак ; под ред. Г. М. Барер. - МЕДпресс-информ, 2008. - С. 227-228.

18. Farbod F. Improvement in rheumatic fever and rheumatic heart disease management and prevention using a health centre-based continuous quality improvement approach / F. Farbod, H. Kanaan, J. Farbod // International Journal of Oral and Maxillofacial Surgery. - 2009. - Vol. 38 (6). - P. 626-631. 19. The evidence base for the efficacy of antibiotic prophylaxis in dental practice / P. B. Lockhart, B. Loven, M. T. Brennan, C. F. Philip // The Journal of the American Dental Association. - 2007. - Vol. 138 (4). - P. 458-474. 20. Clinical periodontology and implant dentistry. 5th edn. / N. P. Lang, J. Lindhe, T. Karring eds. - Blackwell Munksgaard, 2008. - P. 688-689.

21. Shanson D. New British and American guidelines for the antibiotic prophylaxis of infective endocarditis: do the changes make sense? A critical review / D. Shanson // Current Opinion in Infectious Diseases. - 2008. - Vol. 21 (2). - P. 191-199.

stomatolohii - News of Dentistry, 2 (79), 30-34 [in Ukrainian].

4. Boiarchuk, O.R. (2012). Osoblyvosti subklinichnoho perebihu khronichnoi revmatychnoi khvoroby sertsia [Features of subclinical course of chronic rheumatic heart disease]. Ukrainskyi revmatolohichnyi zhurnal - Ukrainian Rheumatologic Journal, 2 (48), 28-32 [in Ukrainian].

5. Kuliavets, C.Iu., Kamenska, E.P., Martymianova, L.O., \& Yabluchanskyi, M.I. (2013). Khronichna revmatychna khvoroba sertsia i taktyka yii likuvannia [Chronic rheumatic heart disease and its treatment tactics]. Medytsyna transportu Ukrainy - Medicine of Transport of Ukraine, 3, 75-79 [in Ukrainian].

6. Knysov, H.V., Vatutin, M.T., Voronkov, L.H., Iliashch, M.H., Riabenko, D.V., \& Tseleuko, V.Ya. (2015). 
Profilaktyka, diahnostyka ta likuvannia infektsiinoho endokardytu. Rekomendatsii robochoi hrupy $\mathrm{z}$ khvorob miokarda, perykarda, endokarda ta klapaniv sertsia Asotsiatsii kardiolohiv Ukrainy [Prevention, diagnosis and treatment of infective endocarditis. Recommendations of the working group on diseases of the myocardium, pericardium, endocardium and heart valves of the Association of cardiologists of Ukraine]. V.M. Kovalenko, O.H. Nesukai (moderators). Ukrainskyi kardiolohichnyi zhurnal - Ukrainian Cardiology Journal, 6, 11-24 [in Ukrainian].

7. Stewart, R., \& West, M. (2016). Increasing evidence for an association between periodontitis and cardiovascular disease. Circulation, 133, 549-551.

8. Farzin, M., Derafshi, R., Ghapanchi, J., Kafsh, A.Z., \& Rezaiee, M. (2016). Oral manifestations of hypertension and rheumatic heart disease: A cross sectional study in elderly patients. Asian J. Med. Pharm. Res., 6 (2), 09-13.

9. Teles, R., \& Wang, C.-Y. (2011). Mechanisms involved in the association between peridontal diseases and cardiovascular disease. J. Oral Diseases, 17 (5), 450-461.

10. Cruz-Pamplona, M., Jimenez-Soriano, Y., \& SarriónPérez, M.G. (2011). Dental considerations in patients with heart disease. J. Clin. Exp. Dent., 3 (2), 97-105.

11. Maharaj, D., \& Vayej, A.C. (2012). Oral health of patients with severe rheumatic heart disease. Cardiovascular Journal of Africa, 23 (5), 336-339.

12. Dhotre, S.V., Davane, M.S., \& Nagoba, B.S. (2017). Periodontitis, bacteremia and infective endocarditis: A review study. Arch. Pediatr. Infect. Dis., 5 (3), e41067.

13. Nakano, K., Nomura, R., \& Ooshima, T. (2008). Streptococcus mutans and cardiovascular diseases. Japanese Dental Science Review, 44 (1), 29-37.
14. Granados-Principal, S., El-Azem, N., Quiles, J.L., PerezLopez, P., Gonzalez, A., \& Ramirez-Tortosa, C, (2012). Relationship between cardiovascular risk factors and periodontal disease: Current knowledge, cardiovascular risk factors. Gasparyan, A. (Ed.). InTech. Ketrieved from: 15. http://www.intechopen.com/books/cardiovascularrisk-factors/relationshipbetween-cardiovascular-riskfactors-and-periodontal-disease-current-knowledge 16. Dinakaran, V. (2017). Microbial translocation in the pathogenesis of cardiovascular diseases: a microbiome perspective. Journal of Cardiology \& Current Research, 8 (6), 00305.

17. Volf, G.F., Ratejchak, Je.M., \& Ratejchak, K. (2008). Parodontologija: rukovodstvo [Parodontology: guideline]. Barer, G.M. (Ed.). MEDpress-inform.

18. Farbod, F., Kanaan, H., \& Farbod, J. (2009). Improvement in rheumatic fever and rheumatic heart disease management and prevention using a health centre-based continuous quality improvement approach. International Journal of Oral and Maxillofacial Surgery, 38 (6), 626-631.

19. Lockhart, P.B., Loven, B., Brennan, M.T., \& Philip, C.F. (2007). The evidence base for the efficacy of antibiotic prophylaxis in dental practice. The Journal of the American Dental Association, 138 (4), 458-474.

20. Lang, N.P., Lindhe, J., \& Karring, T. (Eds.) (2008). Clinical periodontology and implant dentistry (5th edn.). Blackwell Munksgaard.

21. Shanson, D. (2008). New British and American guidelines for the antibiotic prophylaxis of infective endocarditis: do the changes make sense? A critical review. Current Opinion in Infectious Diseases, 21 (2), 191-199.

Отримано 04.09.18 